\title{
"Antropologia theologica»: rationality as a turning point of the Russian orthodox thought
}

\author{
Igor Goncharenko*, Aleksandr Litvinenko, Olga Nifontova ${ }^{1}$ and Irina Strakhova
}

Belgorod National Research University, 308015, Belgorod, Russia

\begin{abstract}
The article presents the results of a study of one of the least known areas of the Russian anthropological tradition, which arose and developed in the interdisciplinary philosophical and theological space of Orthodox thought of the XIX-XX centuries. The authors of the article characterize the most important differences in this interdisciplinary field of anthropological research, referring to several key episodes (cases) of its history. First of all its disciplinary genesis is analyzed - in the writings of the thinkers of the circle of Metropolitan Philaret (Drozdov), where the term Antropologia Theologica (or theological «chelovekoslovie», theological anthropology) arises; the same thinkers systematize and clarify the fundamental concepts of Christian anthropology, both in its Eastern Byzantine version, and those that arised in the historically close Western, Lutheran. Then in the article are proposed the results of the analysis of the works of Bishop Feofan (Govorov), where the Orthodox dominant is developed for a rational and holistic understanding of a person, his nature and composition, which can not be reduced to rational (Aristotelian) human anatomy but containing a certain social minimum of self-movement reasonable social and personal action. Finally in the article are discussed the features of the scientific experimental and philosophical-theological approaches of Archbishop Luke (Voyno-Yasenetsky), medical scientist, philosopher and theologian, continuing the history of a rational and historically diverse Antropologia Theologica.
\end{abstract}

\section{Introduction}

One of the traditional differences of philosophical thought in Russia is an intensive anthropological search. The most active historical area of this search is the «long»XIX century (including the first one and a half decades of the XX century), when questions about a person, his nature purpose and the boundary meanings of human existence were researched with some special, revival enthusiasm. Then, in the lively atmosphere of philosophical conversations works of Plato and Aristotle were translated into Russian, and they were carried away by reflections on the natural human. J.-J. Rousseau read the works of R. Descartes, B. Spinoza, I. Kant, F.W. von Schelling, G.V.F. Hegel, A. Schopenhauer, F. Nietzsche, Edward von Garman, and others, looking for truths in them that would clarify the history of human self-consciousness, its rationally free and unaccountable beginnings.

*Corresponding author: eigor1@yandex.ru 
In that Russian philosophical anthropology it was impossible to do without the last questions about faith and knowledge as conditions of self-knowledge. In university philosophical communities and on the pages of numerous public journals, this questioning is not difficult to notice (up to the magazine Faith and Reason, 1884-1917, where this question was in the title). However, the real revolution - a radical turn in the direction of rational understanding of the deep problems of human experience was accomplished in the interdisciplinary field of philosophical and theological studies. This area is the least of all studied and in our opinion requires special historical and systematic research.

\section{Ways of development of antropologia theologica in the studies of metr. filaret (drozdov) and his students}

In order to clarify the cognitive attitudes of Antropologia Theologica as a terra incognita of Russian anthropology, we have two terms used by researchers who have worked in this field - Latin «antropologia theological» and specifically Russian «theological chelovekoslovie» (a tracing of the Greek word " $\theta v \theta \rho \omega \pi \mathrm{o} \lambda \mathrm{o} \gamma \boldsymbol{\gamma}^{\alpha}$ ) or simply «chelovekoslovie». These terms came into circulation with the advent of essays on philosophical and theological anthropology - in the circle of Metropolitan Philaret (Drozdov) (1783-1867) and his adepts, Archbishop Cyril (Theological-Platonov) (17881841) and Archimandrite Eutykhian (Lestev) (1787-1837). The terms «anthropologia theological» and «theological humanity» appear in the writings of Metropolitan Philaret; The term «human theology» acquires a stable anthropological meaning and means the doctrine of a person in the light of rational-anthropological thinking in the texts of Archimandrite Eutykhian and Archbishop Cyril.

The rational certainty and completeness of the anthropological reflections of Metropolitan Philaret was imparted by his desire for dialogue with thinkers of the Western (primarily Lutheran) philosophical and theological tradition where faith was interpreted as a free gift of God and was learned through Sola Scriptura - rational hermeneutics ecce homo (John 19: 5). (As studies show the anthropologia theologica by M. Filaret was created with frequent reference to the works of the German philosopher and Lutheran theologian Johann Franz Buddei. [1]. In many educational programs of the St. Petersburg Theological Academy prepared with the participation of Metropolitan Philaret was included the works of F. Buddej; Other recommended scholars who thought in the categories of Western theological rationality such as Hollasia, Sardagni, Turretini, Ernesti Schuberti, Teller and others were among the recommended textbooks [2].

Going beyond the boundaries of habitual judgments about dichotomy (soul and body) and trichotomy (spirit, soul and body) he interprets the mental principle in the supposed «composition» of a person: «spirit and mind make up almost one thing that the Apostle truly connects when he expresses truth or the essence of the Christian teaching, which is to be renewed by the spirit of the mind (Eph. 4, 23). If it's possible to identify what is the difference between the mind and the spirit: unless that one a spirit is imaged in the mind as something more sublime, more internal, opening up in the mind like a soul opens in the senses» [3].

Archbishop Cyril reconciles the judgments of Metropolitan Philaret about the composition of a person, referring to the words of the Apostle Paul: «Apostle Paul separates the spirit from the soul. The word of God is alive and effective and passing through to the separation of the soul and spirit. (Heb. 4:12), therefore, the spirit is not the same, that the soul ... it is a power that has a capacity of know, different from that of the higher soul, which understands and feels» [4]. Paulinic accent reinforced by in antropologia theological of Archbishop Cyril allows him with a certain systematic distinction to identify 
four states of human nature to define the «parts» of human (spirit, soul and body) and to characterize their qualities in a state of perfection and in a state of damage etc.

Archimandrid Evtikhian offers a hermeneutic commentary on the writings of Metropolit Philaret significantly clarifying the theological position of his teacher. So, noting following the metropolitan that «the inner part of a person is created by God through the input into him of his breath», and that the soul in the Hebrew text is called «the breath of lives», Archimandrid Evtikhian clarifies that human unites plant life in himself, because «at first he matures and then diminishes dries and finally decays», animal life, because «like animals has a need of food and air», life of angels, because «the main his activity is in reason and whishes»; temporary life, eternal life, «because his spirit is immortal» life in the image of the visible world life in the image of the invisible world finally physical soulful and spiritual life. According to the views of the Archimandrid Evtikhian a person is the focus of numerous types and ways of life unites in himself all the existing possibilities of existence in the world (over a distance). The same fragment in Metropolit Filaret is reduced to listing only without explanation: «... a person really copies in himself the life of plants, animals and angels, life temporary and eternal, life after the image of world and after the image of God» [3].

\section{Theology and mysticism in the tradition of the eastern church: theophan the recluse}

In the second part of the XIX century, antropologia theologica was developed and got the features of a stable, holistic doctrine in the works of bishop Theophanes (Govorov) (18151894). Renewing the rational aspects of the European anthropological tradition he comments the legacy of Aristotle reintegrating Aristotelian rationalism into the semantic field of the mystic-ascetic experience of Christianity (which fully corresponds to the traditions of the founders of Christian activity anthropology in which the «knowledge of those who boast about them no acting is the theology of demons» [6]. A purely rational anthropology closes self-knowledge within its own boundaries - it ideologizes it but «ideas prove only that there are invisible things just as the demand for a food proves that there is a food; and what are those objects what they are where - it still needs to be recognized. Moreover, this indication of the being of the invisible world is not immediate but mediate inferential» [7]. An exceptionally rational anthropology is thus subject-centered destroying the integrity of human existence which is never limited to human himself. Meanwhile «the mind is only the visual spiritual power of world. Obviously, for further development or dispensing of this knowledge, it is necessary to exercise this power of spiritual vision with real vision just as the eye's visual power exercises and diversifies the experience of your vision in real vision» [7].

The conceptual condition of the integral antropologia theologica of the bishop Theophanes (Govorov) becomes not some abstract holistic ideal of a person or human understanding, but active communication - contact with the world and one's own depth: «it is necessary to enter into direct intercourse and contact with that world, as the sensual eye enters such intercourse with sensible things, there is a need to be in communion with God and the spiritual world»[7]. This communication which presupposes human knowledge in connection with the experience of the knowledge of God and, by analogy with it, is communication as the solution of a certain mystic-ascetic task. If to know God means not so much to know about Him, how to see, behold, feel or «partake» Him («partake, and see how good the Lord is!» - (Ps. 33:9) - to unite with Him, then human's self-knowledge in his ultimate informative experienced sincerity is as follows. Antropologia theologica here turns out to be a cognitive practice of trusting in one's own depth, at which the "warmth of God's love for oneself» [8]. is felt and implies an apply to the resources of the «pure heart» 
(Mt 5:8). «Theology», according to the thought of Bishop Theophanes, there is the primordial hermeneutic practice of cognition- $\varphi \imath \lambda i ́ \alpha$ a love-friendly or partly relationship of the knower and the knowable. In this knowledge, the cognitive minimum of faith makes itself felt as a kind of gift an active minimum of the mental and heartfelt communication of a person with his depth - the movement of the «Holy Spirit given to us» (Romans 5:5). «The Holy Spirit is given to every believer. By bringing him into it He brings with Him, he burns and lets his heart feel God's love, God's love for us and our love for God, of which both hold hope for the degree of unconfident confidence. Sensing the warmth of God's love for himself he can not allow any doubt that God, who warms him with His love, will do everything for him according to His promise expected of Him» [9] . (It is noteworthy that the practical context of antropologia theologica forms the «conversational movement» (with a free deeply personal-social organization, the unity of the «world and the clergy» and others) at the source of which is the senior contemporary of Russian philosophical and theological anthropological research prep. Seraphim of Sarovsky (1754 or 1759 - 1833) [10] . It is also relevant to note that the anthropological reflections of Bishop Theophane (Govorov) found a continuation and development in Russian theology of the XX century the writings of Bishop Basil (Krivoshein), father of George Florovsky, Protopresbyter John Meyendorff, Vladimir Lossky and others.

\section{Scientific and theological synthesis «Antropologia Theological» in the writings of Archbishop luka (Voyno- Yasenetsky)}

At the end of the XIX century and the first decades of the XX century, when anthropological problems were developed in experimental natural science and on the other hand in various phenomenological forms of philosophical research the a unique evidence of cognitive tension existing in Russian antropologia theologica became the works of one of the leading Russian scientists doctors and at the same time the theologian hierarch of the Russian Orthodox Church, Archbishop Luka (Voyno-Yasenetsky) (1877-1961). In his work «Spirit, Soul, Body» Archbishop Luka reviews the theory of the higher nervous activity of I.P. Pavlov through the conceptual prism of A. Bergson's intuitivism and existentially oriented philosophy of life taking into account the materials of both the history of European self-consciousness and the latest empirical body of physiological (reflexological) research. The heart is at the center of attention - «a special sense organ, a center of emotions, and an organ of our knowledge» [11]. Clarifying the value of the discoveries of Pavlov Archbishop Luka argues that the heart and similar categories by its cognitive nature are quite open: «our anatomical and physiological knowledge of the heart not only does not interfere, but rather even induces us to consider the heart as the most important sensory organ and not just the central circulatory motor» [11].

The scientific and physiological ideas about the heart always aspectually limited, «superficially sophistic» (Compare: «In science there are no 'depths'; there is surface everywhere: all experience forms a complex network, which cannot always be surveyed and can often be grasped only in parts. Everything is accessible to man; and man is the measure of all things. Here is an affinity with the Sophists, not with the Platonists'; with the Epicureans, not with the Pythagoreans; with all those who stand for earthly being and the here and now») [12], in the theology of Archbishop Luka they are completed culturally historically in the space of cognitive intuitions and the open cognitive integrity of antropologia theologica. He notes that even the ancient Greeks had a special attitude to this human organ, for naming which there were several separate words meaning not only physical processes but also soul, mind, mood, thought, persuasion, opinion. On the 
language of Russian culture the heart «suffers», «hurts», «rejoices», «feels», «depresses» so it takes on the functions of an organ of the soul it is modified «as if an organ of sense and moreover extremely subtle and universal» [11]. The category of the heart thus becomes a condition for the cognitive processing of the most active, spiritual human talk, communion with God, «and consequently» the heart «is the organ of higher knowledge» [11] . Archbishop Luka turning to that category, Luka shows himself a contemporary and in essence a companion of thinkers who interpreted the long-standing Pascal idea of the "logic of the heart" in the general context of the history of philosophy of the first half of the XX century, when paradigmatic sources and foundations of philosophical thinking were reviewed with ever-increasing zeal [13].

\section{Conclusion}

1.The XIX century in the history of Russian philosophical thought manifested itself in versatile and intensive anthropological research. One of the least studied areas of the anthropological movement of that time was the space of philosophical and theological thought where the traditional anthropological questions about faith, knowledge and selfknowledge were revised and presented in the form of a new rational-active synthesis «antropologia theological» («theological humanitytalk»).

2. Having arisen in the circle of thinkers who are close to Metropolitan Filaret (Drozdov), antropologia theologica becomes a kind of hermeneutics of the Paulinian gnosis the beginning of a returnable understanding of free and socially-personal principles of Christian anthropology such an understanding assumed the oriental experience of «transforming» thinking and the western experience, philosophy and theology of Luther's reformation, strove for it.

3. The key conceptual structure reinterpreted during the historical movement of the Russian antropologia theologica was Aristotle's philosophy of human. In the writings of Bishop Theophane (Govorov) with exceptional thoroughness develop the Aristotle's meanings of the active understanding of human as entering into communion with the world and God; "Theology» here appears in connection with the experience of theology (including mystic-rational) and by analogy with it.

4. In the field of scientific and theological synthesis «antropologia theological» is actually presented in the writings of Archbishop Luka (Voyno-Yasenetsky) a very famous medical scientist, philosopher and theologian who compared the foundations and cognitive structures of the experience of the physiological and religious-philosophical categories of anthropological experience, the minimalist attitudes of A. Bergson's intuitivism and the fullness of Christian caring for a person his «heart».

5. The conceptual renewal of Russian interdisciplinary theological anthropology has a well-defined research perspective and is relevant in the cognitive situation of our time of the beginning of the XXI century «after history». There is an opportunity to clarify not only historical but also modern practices of anthropological research in Russia their involvement in the world movement of Christian philosophical and anthropological thought and their own originality (anthropological intentions of neo-patristic synthesis, interpretation of the heritage of Gregory Palamas, energy anthropology of Sergey S. Khoruzhy, etc.).

\section{Research method}

The study represents a systematic analytical description (with elements of hermeneutical reconstruction) of anthropological attitudes and conceptual semantic and anthropological characteristics contained in the philosophical and theological writings of Russian Christian (Orthodox) thinkers of the XIX-XX centuries.

\section{References}


1. Buddeus Johann Franz. Io. Francisci Buddei, Institutiones theologiae dogmaticae variis observationibus illustratae (Francofurti; Lipsiae 1741). - [10], (1320). 20.

2. I. Chistovich, Istoriya S. Peterburgskoj duxovnoj akademii, cochinenie e`kstraordinarnago professora S. Peterburgskoj duxovnoj akademii Ilariona Chistovicha (Sankt-Peterburg: v Tip. Yakova Treya., IV, 1857)

3. Aleksej Gorodkov, Dogmaticheskoe bogoslovie po sochineniyam Filareta, mitr. Moskovskogo (Tip. Gubernskogo pravleniya, Kazan, 1887)

4. Kirill (Bogoslovskij-Platonov), arxiep., Bogoslovie sozerczatel 'noe: 1,2,3,4 [rukopis ']: kurs lekcij Kirilla, chitanny`x im v Moskovskoj duxovnoj akademii - [B.m.], XIX v. 79 [II] 1. OR F.304. 2 №155; 72 [II] 1. OR F. 304.2 №156; 65 [III] 1. OR F. 304.2 №157; 110 [II] 1. OR F. 304. 2 №158., (1887)

5. Aleksej Gorodkov, Dogmaticheskoe bogoslovie po sochineniyam Filareta, mitr. Moskovskogo (Tip. Gubernskogo pravleniya, Kazan,1887.)

6. Maksim Ispovednik, prep. (Pisma, Spb., 2008) (1887)

7. Feofan Govorov, svyatitel', Nachertanie xristianskogo nravoucheniya. Information on https://azbyka.ru/otechnik/Feofan_Zatvornik/nachertanie-hristianskogonravouchenija/3\#h417.

8. Feofan Govorov, svyatitel', Voploshchennoe domostroitel'stvo. Opyt hristianskoj psihologii. Information on https://azbyka.ru/otechnik/Feofan_Zatvornik/voploshennoedomostroitelstvo-opyt-hristianskoj-psihologii/

9. Feofan Zatvornik, svyatitel', Tolkovanie pervy`x vos 'mi glav Poslaniya sv. Apostola Pavla $k$ Rimlyanam. Information on https: //azbyka.ru/otechnik/Feofan_Zatvornik/tolkovanie-k-rimljanam/3

10. A. Dudarev, Eksperimental'naya teologiya. Information on https://predanie.ru/book/218734-eksperimentalnaya-teologiya/

11. Svyatitel’ Luka (Vojno-Yaseneczkij), Nauka i religiya; Dux, dusha i telo (Feniks, Troiczkoe slovo, 2001)

12. Carnap, Rudolf, Hans Hahn and Otto Neurath, Wissenschaftliche Weltauffassung - Der Wiener Kreis, Wien Wolf, partial transl. in Neurath (1973). 299-318, (full trans. in Stadler and Uebel,2012)

13. P.D. Yurkevich, Serdce i ego znachenie v duxovnoj zhizni cheloveka po ucheniyu Slova Bozhiya (Pravda, Moscow, 1990) 